\title{
EXTRACTION AND PURIFICATION OF PGM SOLUTIONS OBTAINED FROM METALLURGICAL TREATMENT OF USED AUTOMOTIVE CATALYTIC CONVERTERS
}

\author{
${ }^{1}$ Mariola SATERNUS, ${ }^{1}$ Agnieszka FORNALCZYK, ${ }^{2}$ Władysław GĄSIOR, ${ }^{2}$ Adam DĘBSKI, \\ ${ }^{2}$ Sylwia TERLICKA
}

${ }^{1}$ Silesian University of Technology, Faculty of Materials Engineering and Metallurgy, Gliwice, Poland, EU, mariola.saternus@polsl.pl

2Institute of Metallurgy and Materials Science, Polish Academy of Sciences, Cracow, Poland, EU, w.gasior@imim.pl

https://doi.org/10.37904/metal.2019.759

\begin{abstract}
Today, the demand for platinum is constantly growing. It is related to its use as a catalyst mainly in the production of cars. Car production has been increased year by year, consequently the used catalytic converters is the biggest problem. On the one hand, it is a waste, on the other it is also a source of valuable and precious metals. Thus, the automotive catalytic converter is treated hydrometallurgically and pyrometallurgically to recover valuable metals. However, this process is not so easy. After obtaining solutions containing precious metals from hydrometallurgical methods or alloys of the metal collector with PGM (Platinum Group Metals) from pyrometallurgical methods there should be separation and purification of PGM. These processes are difficult and complicated due to their resistance to chemicals attack and the ability to create many chemical compounds. The article presents and discusses the possible methods of separation and purification of platinum and PGM (e.g. liquid-liquid extraction, adsorption, ion exchange).
\end{abstract}

Keywords: Automotive catalytic converter, platinum recovery, metallurgical treatment, PGM separation

\section{INTRODUCTION}

Today, the use of precious metals, such as silver, platinum, rhodium, palladium, is constantly growing due to their catalytic properties [1]. Platinum is particularly popular, but the natural resources of platinum group metals (PGM) are limited and shrinking. The availability of PGM in the future is questionable considering their high demand in recent years (see Table 1); social, economic, environmental as well as political aspects connected with their production (see Table 2).

Table 1 Supply, demand and recycling of platinum, palladium and rhodium [2]

\begin{tabular}{|c|c|c|c|}
\hline Metal & Supply $(\mathrm{kg})$ & Demand $(\mathrm{kg})$ & Recycling $(\mathrm{kg})$ \\
\hline $\mathrm{Pt}$ & 169,400 & 222,400 & 56,000 \\
\hline $\mathrm{Pd}$ & 187,020 & 287,800 & 82,950 \\
\hline $\mathrm{Rh}$ & 21,260 & 29,710 & 9,180 \\
\hline
\end{tabular}

Table 2 Primary production of palladium and platinum in 2017 and 2018 [3]

\begin{tabular}{|c|c|c|c|c|c|c|c|c|}
\hline \multirow{2}{*}{ Metal } & \multirow{2}{*}{ Year } & \multicolumn{7}{|c|}{ Production (kg) } \\
\cline { 3 - 10 } & & Total & USA & Canada & Russia & RSA & Zimbabwe & Other \\
\hline \multirow{2}{*}{ Pd } & 2017 & 225,000 & 13,600 & 17,000 & 85,200 & 86,800 & 12,000 & 10,800 \\
\cline { 2 - 10 } & 2018 & 210,000 & 14,000 & 17,000 & 85,000 & 68,000 & 12,000 & 11,000 \\
\hline \multirow{2}{*}{ Pt } & 2017 & 199,000 & 3,980 & 9,500 & 21,800 & 143,000 & 14,000 & 6,510 \\
\cline { 2 - 10 } & 2018 & 160,000 & 4,100 & 9,500 & 21,000 & 111,000 & 14,000 & 6,100 \\
\hline
\end{tabular}


To almost exclusive producers of primary platinum belongs South Africa - nearly $70 \%$. However, in 2018 the production is decreased compared to 2017 mainly due to the reduction of employment and mine-shaft closures. Over the next two to three years, this production in South Africa is expected to decline as one of the leading PGM companies have announced a 13,000 job reduction in part of its mine [4]. In the case of palladium, the situation is better due to the fact that production takes place not only in South Africa, but also in Russia ( $40 \%)$, Canada ( $8 \%$ ) and USA ( $7 \%)$. That is why waste materials are becoming a valuable source of platinum group metals. An important advantage of such materials is the high concentration level compared to the basic sources [4-6], therefore the recycling of PGM from the spent automotive catalytic converters becomes a necessity.

\section{METALLURGICAL TREATMENT OF USED AUTOMOTIVE CATALYTIC CONVERTERS}

There are many methods used for PGM recycling from used automotive catalytic converters based on pyrometallurgical and hydrometallurgical treatment. In a pyrometallurgical manner, catalytic converter carriers are smelted with various metals (called collector metals), such as copper, iron or lead [7-12]; platinum went to the metal collector, while the alumina carrier formed slag. Figure 1a shows a typical pyrometallurgical treatment of used automotive catalytic converters with copper as a metal collector - the produced alloy is then electrorefined to separate platinum group metals. Figure $\mathbf{1 b}$ presents a diagram of a modified metal collector method using a magneto-hydro-dynamic pump for flushing platinum from a catalytic converters and creating a closed loop. In addition, the whole carriers are used in this method, whereas in the copper collector method the carriers are ground, milled and homogenized. In industry pyrometallurgical methods are used [13] because are effective, but on the other hand, they are slow and energy-consuming.
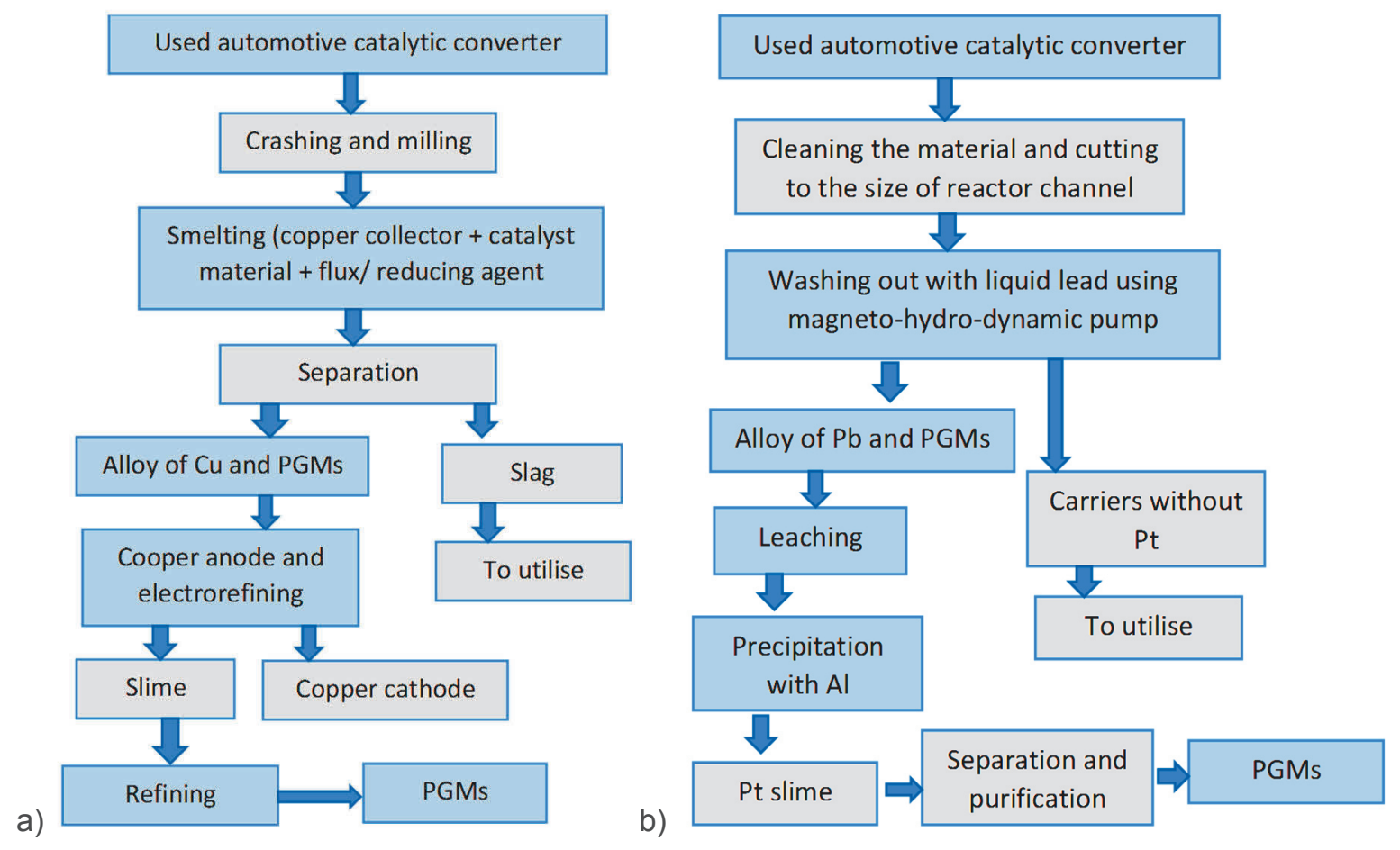

Figure 1 Pyrometallurgical treatment of used automotive catalytic converters: a) copper as metal collector, b) modified method with magneto-hydro-dynamic pump and lead as metal collector [7-9]

The second method is hydrometallurgical treatment (commonly used for the recovery of non-ferrous metals from waste materials, such as catalyst or printed circuit boards [14-16]). They are divided into two groups: 
- $\quad$ used directly (feed digestion) - leaching in various media, such as chlorine, chlorides, aqua regia, with addition of $\mathrm{H}_{2} \mathrm{O}_{2}, \mathrm{H}_{2} \mathrm{O}_{2}$ and sulphuric acid, cupric ions [17-20] - see Figure 2a,

- $\quad$ used after pretreatment methods (e.g. thermal pretreatment) or pyrometallurgical methods and leaching - solution purification with metals separation using solvent extraction.

Hydrometallurgical methods in comparison with pyrometallurgical methods consume less energy, but the recycling efficiency is not so high and a large amount of waste solutions is also generated. In both cases it is necessary to further process the product obtained: pyrometallurgical alloy of a metal collector with platinum group metals and hydrometallurgical solutions with PGM. The platinum-copper alloy may be electrorefined for platinum recycling; whereas precipitation, extraction methods or ion-exchange can be applied for separation and purification of PGM from solutions [21-25].

\section{SEPARATION AND PURIFICATION OF PGM SOLUTION}

As mentioned earlier, many researchers have investigated the extraction and separation of platinum group metal from aqueous solutions, but this process is still difficult and complicated due to the similarity of physical and chemical properties of PGM. Therefore, they are resistant to chemical attack and at the same time have the ability to create many chemical compounds in chloride solutions. Various methods are applied as precipitation, ion-exchange and adsorption or solvent extraction (liquid-liquid extraction - an aqueous solution of PGM ions and organic solution of an extractant). Solvent extraction is one of the most important and often proposed techniques for the selective recovery of PGM ions from various solutions. Figure $2 \mathbf{b}$ shows the solvent extraction scheme used for metal recovery. Table 3 shows the main characteristics of the various methods used to extract and separate PGM, while Table 4 presents typical commercial extractants used for the recovery of platinum group metals from catalyst leaching solutions. Figure 3 shows a scheme of Pt(IV), $\mathrm{Pd}(\mathrm{II}), \mathrm{Rh}(\mathrm{III})$ and Ir(IV) separation from hydrochloric acid solutions by solvent extractions.

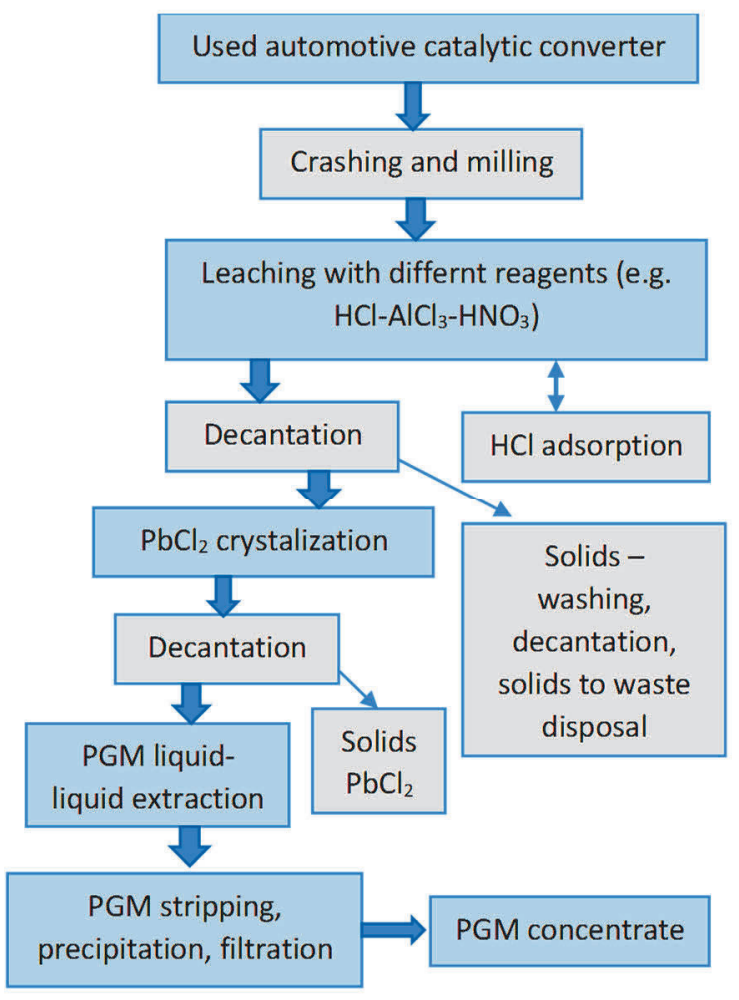

a)

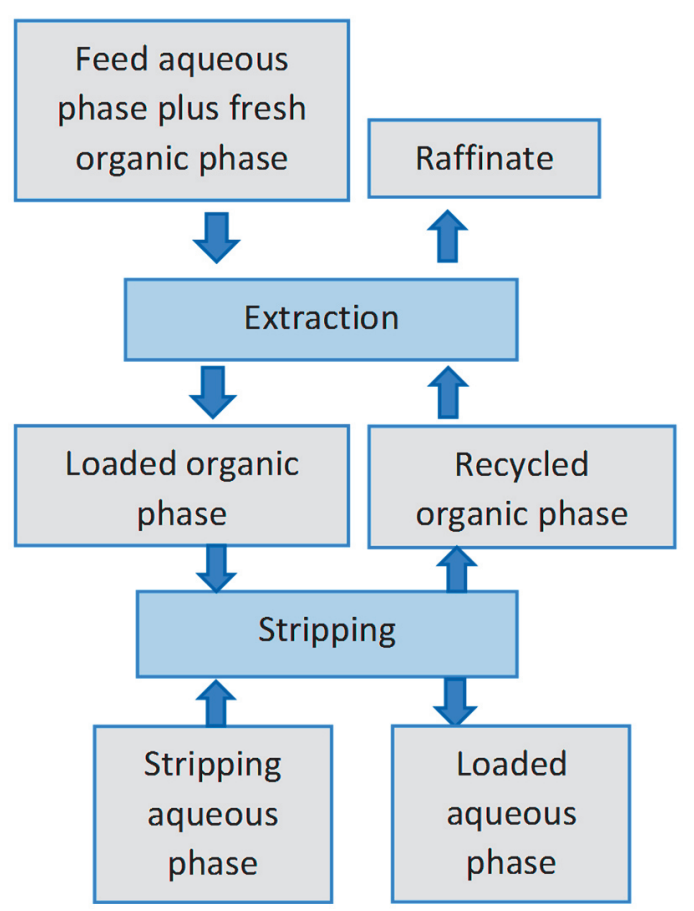

b)

Figure 2 a) Hydrometallurgical treatment of used automotive catalytic converters, b) solvent extraction scheme applied for platinum group metals recovery $[22,23]$ 
Table 3 Characteristics of methods used for extraction and separation of PGMs from aqueous solutions $[20,22,23]$

\begin{tabular}{|c|l|}
\hline Method & \multicolumn{1}{c|}{ Characteristics } \\
\hline Precipitation & $\begin{array}{l}\text { Addition of different chemical reagents such as zinc or aluminium powder, ammonium chloride which } \\
\text { gives Pt precipitate, leaving the accompanying platinum group metals in solution. }\end{array}$ \\
\hline $\begin{array}{c}\text { Adsorption } \\
\text { and ion- } \\
\text { exchange }\end{array}$ & $\begin{array}{l}\text { Anion-exchange process took place only on the surface of the adsorbent, therefore the loading or the } \\
\text { exchange capacity of adsorbents is relatively smaller when compared with ion-exchange resins; in } \\
\text { adsorption the most important parameters are the characteristics of surface and the pores of adsorbents; } \\
\text { ion-exchange relies on passing a metal ion-containing solution through bed of solid ion-exchange resin: } \\
\text { metal ions are exchanged with the ions of the resin carrying accessible cations, anions or amphoteric } \\
\text { ions, then the pregnant resin is washed with another aqueous solution to elute the adsorbed metal ions } \\
\text { and to regenerate resin; typical adsorbents and resins used for removal Pd(II) and Pt(IV): Lewatit TP } \\
\text { 214, Amberlite IRA-478RF, Amberlite XAD-1180, Amberlite XAD-7, Dowex MSA-1, Purolite S-984, } \\
\text { Purolite A-830, MP-102, TAPEHA, activated C, alumina nanopowder. }\end{array}$ \\
\hline $\begin{array}{c}\text { Solvent } \\
\text { extraction }\end{array}$ & $\begin{array}{l}\text { Includes an extraction and a stripping stage, in extraction the feed aqueous phase contacts with an } \\
\text { efficient and selective extractants, the loaded solvent is then equilibrated with a stripping aqueous } \\
\text { medium, which causes the transfer of the metal to the new aqueous solution. }\end{array}$ \\
\hline
\end{tabular}

Table 4 Typical commercial extractants applied for platinum group metals recovery from catalyst leaching solutions $[20,22-30]$

\begin{tabular}{|c|c|}
\hline Extractants & Comments \\
\hline Alamine 300 & $\begin{array}{l}\text { Separation of } \mathrm{Pt}(\mathrm{IV}) \text { and } \mathrm{Pd}(\mathrm{II}) \text { from chloride solution using Alamine } 300 \text { at } 0.001-0.01 \mathrm{M} \text { in presence } \\
\text { of } 0.5 \mathrm{M} \mathrm{HCl} \text { in the aqueous phase, } 99.99 \% \mathrm{Pt} \text { and } 98 \% \mathrm{Pd} \text { can be separated. }\end{array}$ \\
\hline Alamine 308 & Typical for Pd(II), poorly selective over Pt(IV) and other metals. \\
\hline Alamine 336 & $\begin{array}{l}\text { Extraction of ruthenium about } 72 \%, 5 \% \text { solution of Alamine } 336 \text { in kerosene was used for co- } \\
\text { extraction of } \mathrm{Pt}(\mathrm{IV}) \text { and } \mathrm{Fe}(\mathrm{III}), 0.5 \mathrm{M} \text { thiourea and } 0.1 \mathrm{M} \mathrm{HCl} \text { solution were used for stripping of these } \\
\text { metals, purity of } \mathrm{Pd}(\mathrm{II}) \text { and } \mathrm{Pt}(\mathrm{IV}) \text { were } 99.7 \% \text {. }\end{array}$ \\
\hline LIX841 & $\begin{array}{l}\text { Selective for } \mathrm{Pd}(\mathrm{II}) \text { for leaches at } \mathrm{pH} \text { 2; separation of } \mathrm{Pt}(\mathrm{IV}) \text { and } \mathrm{Pd}(\mathrm{II}) \text { from associated metals such } \\
\text { as } \mathrm{Fe}(\mathrm{III}), \mathrm{Cu}(\mathrm{II}), \mathrm{Ni}(\mathrm{II}), \mathrm{Zn}(\mathrm{II}), \mathrm{Al}(\mathrm{III}) \text { by } 0.5 \% \mathrm{LIX} 841 \text { in kerosene. }\end{array}$ \\
\hline Cyanex 921 & $\begin{array}{l}\mathrm{Pd}(\mathrm{II}), \mathrm{Pt}(\mathrm{IV}) \text { and } \mathrm{Rh}(\mathrm{III}) \text { co-extracted, but separated in the presence of tin(II) chloride, rapid for the } \\
\text { separation of } \mathrm{Pt}, \mathrm{Pd} \text { and } \mathrm{Rh} \text { with the recovery efficiency about } 99.8 \% \text {. }\end{array}$ \\
\hline Cyanex 923 & $\begin{array}{l}\text { Extraction of } \mathrm{Pt}(\mathrm{IV}) \text { from } \mathrm{HCl}: 70-100 \% \text {, from sulfuric or nitric acid: } 55 \% \text {, extraction of } \mathrm{Pd}(\mathrm{II}) \text { from } \\
\mathrm{HNO}_{3}: 70 \% \text {, extraction of } \mathrm{Rh}(\mathrm{III}) \text { from } \mathrm{HNO}_{3}: 35 \% \text {. }\end{array}$ \\
\hline Cyanex 471x & $\begin{array}{l}\text { Selective } \mathrm{Pd}(\mathrm{II}) \text { separation from low concentrated } \mathrm{HCl} \text {; extraction of } \mathrm{Pd}(\mathrm{II}) \text { decreases with increasing } \\
\mathrm{HNO}_{3} \text { concentration up to } 2 \mathrm{M} \text { then becomes constant from } 92 \% \text { to } 80 \% \text {. }\end{array}$ \\
\hline $\begin{array}{l}\text { TBP and Aliquat } \\
\quad 336\end{array}$ & $\begin{array}{l}\mathrm{Pd}(\mathrm{II}) \text { and } \mathrm{Pt}(\mathrm{IV}) \text { co-extracted; selective and quantitative } \mathrm{Pd}(\mathrm{II}) \text { extraction even at the lowest } \\
\text { extractant concentration, } 99.95 \% \mathrm{Pd}(\mathrm{II}) \text { separation from raffinate; in second stage } 99.7 \% \mathrm{Pt}(\mathrm{IV}) \\
\text { extraction from } \mathrm{Pd}-\mathrm{Fe} \text { free raffinate at } 0.011 \mathrm{M} \text { Aliquat } 336 \text {; TBP in kerosene gives extraction of } \mathrm{Pt}(\mathrm{IV}) \\
\text { about } 80 \%, \mathrm{Rh}(\mathrm{III}) \text { and } \mathrm{Ir}(\mathrm{III}) \text { remain in raffinate. }\end{array}$ \\
\hline $\begin{array}{l}\text { Cyphos } 101 \mathrm{IL} \\
\text { (ionic liquid) }\end{array}$ & $\begin{array}{l}\text { Selective } \mathrm{Pd}(\mathrm{II}) \text { separation from low concentrated } \mathrm{HCl} \text {, in pure form able to extract } \mathrm{Pd}(\mathrm{II}) \text { from } 1-8 \mathrm{M} \\
\mathrm{HCl} \text {; extraction of } \mathrm{Pd}(\mathrm{II}) \text { from } 45 \% \text { to } 97 \% \text { depending on } \mathrm{HCl} \text { concentration. }\end{array}$ \\
\hline Cyphos 102 IL & om 1-8M HCl, with $\mathrm{Pt}(\mathrm{IV})$ co-extraction. \\
\hline
\end{tabular}

\section{CONCLUSION}

Methods for recovering PGM from used automotive catalytic converters can be based on pyro- or hydrometallurgical processes. Both have advantages or disadvantages, pyrometallurgical processes depend on energy consumption; however, it can give large-scale industrial production. Hydrometallurgical methods are more effective, but generate a lot of waste. On the other hand, it is still more ecological than pyrometallurgy and more flexible in terms of composition and grade of the processed materials. Both processes, however, give products that should be further separated, purified or concentrated. Solvent extraction is a conventional 
operation for the treatment of leaching solutions when hydrometallurgical recycling is considered. In the case of pyrometallurgical treatment, the obtained alloy should be directly applicable (it will be the best solution) or hydrometallurgically treated to separate the platinum and other precious metals.

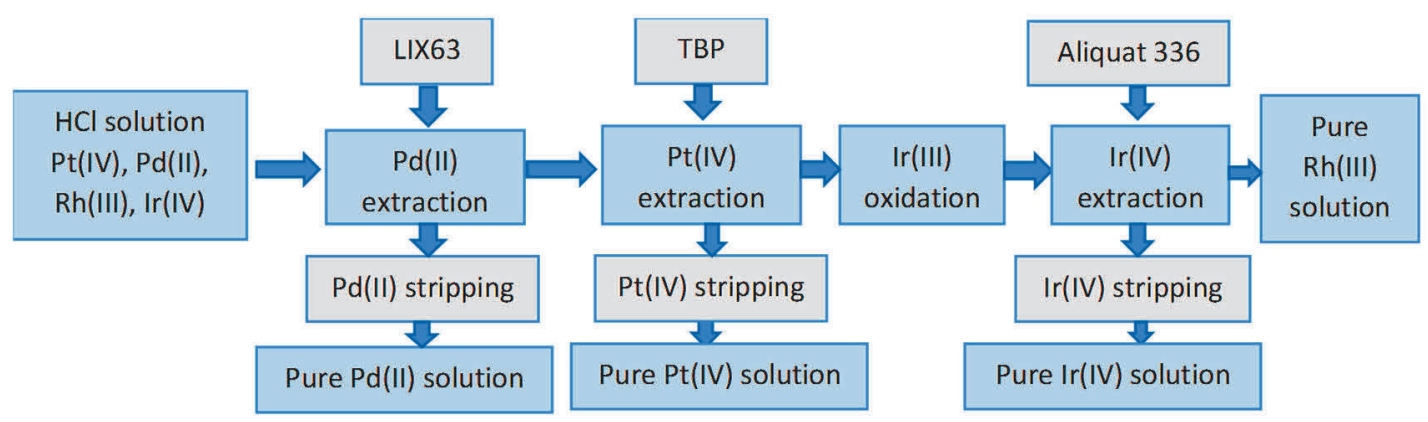

Figure 3 Diagram of the separation of $\mathrm{Pt}(\mathrm{IV}), \mathrm{Pd}(\mathrm{II}), \mathrm{Rh}(\mathrm{III})$ and $\operatorname{Ir}(\mathrm{IV})$ ions from hydrochloric acid solutions by solvent extractions [28]

\section{ACKNOWLEDGEMENTS}

\section{The authors gratefully acknowledged the support from the National Science Centre Poland (NCN) within the research project 2017/27/B/ST8/01464.}

\section{REFERENCES}

[1] SATERNUS, Mariola, FORNALCZYK Agnieszka, WILLNER Joanna, and KANIA Henryk. Methods for silver recovery from by-products and spent materials. Przemysł Chemiczny. 2016. vol. 95, pp. 78-83.

[2] http://www.platinum.matthey.com - pgm_market_report_february_2018.pdf, 17.04.2019.

[3] https://minerals.usgs.gov/minerals/pubs/commodity/platinum/mcs-2019-plati.pdf, 17.04.2019.

[4] SUORANTA, Terhi, ZUGAZUA., Oihane, NIEMELA, Matti and PERAMAKI Paavo. Recovery of palladium, platinum, rhodium and ruthenium from catalyst materials using microwave-assisted leaching and cloud point extraction. Hydrometallurgy. 2015. vol. 154, pp. 56-62.

[5] JHA, Manis Kumar, LEE, Jae-Chun, KIM, Min-Seuk, JEONG, Jinki, KIM, Byung-su and KUMAR, Vinay. Hydrometallurgical recovery/recycling of platinum by the leaching of spent catalyst: a review, Hydrometallurgy. 2013. vol. 133, pp. 23-32.

[6] HAGELUKEN, Christian. Recycling the platinum group metals: a European perspective. Platin. Met. Rev. 2012. vol. 56, pp. 29-35.

[7] FORNALCZYK, Agnieszka, GOLAK, Sławomir and SATERNUS, Mariola. Model of infiltration of spent automotive catalyst by molten metal in process of platinum metals recovery. Mathematical Problems in Engineering. 2013. Article no 461085.

[8] GIL, Stanisław, BIALIK, Wojciech, SATERNUS, Mariola and FORNALCZYK, Agnieszka. Thermal balance of the magneto-hydro-dynamic pump for recovery of platinum group metals from spent auto catalyst. Archives of Metallurgy and Materials. 2016. vol. 61, pp. 253-256.

[9] FORNALCZYK, Agnieszka and SATERNUS, Mariola. Vapour treatment method against other pyro- and hydrometallurgical processes applied to recover platinum from used auto catalytic converters. Acta Metallurgica Sinica English Letters. 2013. vol. 26, pp. 247-256.

[10] PENG, Zhiwei, LI, Zhizhong, LIN, Xiaolong, TANG, Huimin, YE, Lei, MA, Yutian, RAO, Mingjun, ZHANG, Yuanbo, LI, Guanghui and JIANG, Tao. Pyrometallurgical recovery of platinum group metals from spent catalyst. JOM. 2017. vol. 69, pp.1553-1562.

[11] DONG, Haigang, ZHAO, Jiachun, CHEN, Jialin, WU, Yeodong and LI, Boije. Recovery of platinum group metals from spent catalyst: A review. International Journal of Mineral Processing. 2015. vol. 145, pp. 108-113. 
[12] GHODRAT, Maryam, PEJMAN, Sharafi and SAMALI, B. Recovery of platinum group metals out of automotive catalytic converters scrap: a review on Australian trends and challenges: Materials Processing Fundamentals, 2018. https://www.researchgate.net/publication/322334553 Recovery of Platinum Group Metals Out of Automotive Catalytic Converters Scrap A Review on Australian Trends and Challenges. 18.04.2019.

[13] CRUNDWELL, Frank, MOATS, Michael, RAMANCHANDRAN, Venkoba, ROBINSON, Timothy and DAVENPORT, W.G. Recycling of Nickel, Cobalt and Platinum-Group Metals. Extractive Metallurgy of Nickel, Cobalt and Platinum Group Metals. Oxford: Elsevier Ltd., 2011. pp. 537-549.

[14] BROZOVA, Silvie, PUSTEJOVSKA, Pavlina, JURSOVA, Simona and INGALDI, Manuela. Economic and technological aspects of the use of secondary metal-bearing raw materials for metallurgical production. In METAL 2014: 23rd International Conference on Metallurgy and Materials. Ostrava: TANGER, 2014. pp. 1618-1622.

[15] LISIŃSKA, Magdalena, SATERNUS, Mariola and WILLNER, Joanna. Research of leaching of the printed circuit boards coming from waste mobile phones. Archives of Metallurgy and Materials. 2018. vol. 63, pp. 143-147.

[16] FORNALCZYK, Agnieszka and SATERNUS, Mariola. Catalytic converters as a source of platinum. Metalurgija. 2011. vol. 50, pp.261-264.

[17] JIMENEZ DE ABERASTURI, Dorleta, PINEDO, Ricardo, RUIZ DE LARRAMENDI, Idoia and ROJO, Teofilo. Recovery by hydrometallurgical extraction of the platinum-group metals from car catalytic converters. Minerals Engineering. 2011. vol. 24, pp. 505-513.

[18] HARJANTO, Sri, CAO, Yucai, SHIBAYAMA, Atsushi, NAITOH, Isao, NANAMI, Toshiyuki, KOICHI, Kasahara, OKUMURA, Yoshiharu, LIU, Kejun and FUJITA, Toyohisa. Leaching of Pt, Pd and Rh from automotive catalyst residue in various chloride based solutions. Materials Transactions. 2006. vol. 47. pp. 129-135.

[19] PAIVA, Ana P., OLIVEIRA, Paula C., COSTA, Maria Clara and ROSA DA COSTA, Ana M. Oxidative leaching process with cupric ion in hydrochloric acid media for recovery of $\mathrm{Pd}$ and $\mathrm{Rh}$ from spent catalytic converters. Journal of Hazardous Materials. 2014. vol. 278, pp. 82-90.

[20] POŚPIECH, Beata. Studies of platinum recovery from solutions after leaching of spent catalysts by solvent extraction. Physicochemical Problems of Mineral Processing. 2012. vol. 48, pp. 239-246.

[21] BARAKAT, M. A. and MAHMOUD, M.H.H. Recovery of platinum from spent catalyst. Hydrometallurgy. 2004. vol. 72, pp. 179-184.

[22] PAIVA, Ana Paula. Recycling of palladium from spent catalyst using solvent extraction - some critical points. Metals. 2017. vol. 505, no 7, pp. 1-16.

[23] RZELEWSKA, Martyna and REGEL-ROSOCKA, Magdalena. Wastes generated by automotive industry - Spent automotive catalysts. Physical Sciences Reviews. 2018. No. 20180021, pp. 1-27.

[24] RAJU, B., KUMAR, J. Rajesh, LEE, Jin-Young, KANTAM, M.L. and REDDY, B. Ramachandra. Separation of platinum and rhodium from chloride solutions containing aluminum, magnesium and iron using solvent extraction and precipitation methods. Journal of Hazardous Materials. 2012. vol. 227-228, pp. 142-147.

[25] REDDY, B. Ramachandra, RAJU, B., LEE, Jin-Young and PARK, H.K. Process for separation and recovery of palladium and platinum from spent automobile catalyst leach liquor using LIX 841 and Alamine 336. Journal of Hazardous Materials. 2010. vol. 280, pp. 253-258.

[26] SWAIN, Basudev, JEONG, Jinki, KIM, Soo-kyoung and LEE, Jae-Chun. Separation of platinum and palladium from chloride solutions by solvent extraction using Alamine 300. Hydrometallurgy. 2010. vol. 104, pp. 1-7.

[27] LEE, Jin-Young, RAJU, B., KUMAR B. Nagaphani, PARK, H.K. and REDDY, B. Ramachandra. Solvent extraction separation and recovery of palladium and recovery of palladium and platinum from chloride leach liquors of spent automobile catalyst. Separation and Purification Technology. 2010. vol. 73, pp. 213-218.

[28] NGUYEN, Thi Hong, SONU, Chong Ho and LEE, Man Seung. Separation of Pt(IV), Pd(II), Rh(III) and Ir(III) from concentrated hydrochloric acid solutions by solvent extraction. Hydrometallurgy. 2016. vol. 164, pp. 71-77.

[29] LEE, Jin-Young, KUMAR, J. Rajesh, KIM, Joon-Soo, KIM, Dong-Jin and YOON, Ho-Sung. Extraction and separation of $\mathrm{Pt}(\mathrm{IV}) / \mathrm{Rh}(\mathrm{III})$ from acidic chloride solutions using Aliquat 336. Journal of Industrial and Engineering Chemistry. 2009. vol. 15, pp. 359-364.

[30] TRUONG, Hoai Thanh and LEE, Man Seung. Separation of Pd(II) and Pt(IV) from hydrochloric acid solutions by solvent extraction with Cyanex 301 and LIX 63. Minerals Engineering. 2018. vol. 115, pp. 13-20. 